\title{
Challenges to Counselling and Psychotherapy
}


Also by Alex Howard

Finding a Way: A Realist's Introduction to Self-help Therapy Anatomy of Errors: A Self-help Course in Problem-solving Getting Through to You: A Self-help Course in Communication Skills 


\title{
Challenges to Counselling and Psychotherapy
}

\author{
ALEX HOWARD
}

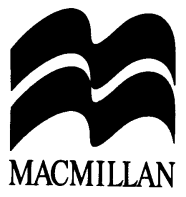




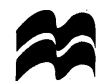

(C) Alex Howard 1996

All rights reserved. No reproduction, copy or transmission of this publication may be made without written permission.

No paragraph of this publication may be reproduced, copied or transmitted save with written permission or in accordance with the provisions of the Copyright, Designs and Patents Act 1988, or under the terms of any licence permitting limited copying issued by the Copyright Licensing Agency, 90 Tottenham Court Road, London W1P 9HE.

Any person who does any unauthorised act in relation to this publication may be liable to criminal prosecution and civil claims for damages.

First published 1996 by

MACMILLAN PRESS LTD

Houndmills, Basingstoke, Hampshire RG21 2XS

and London

Companies and representatives

throughout the world

ISBN 978-0-333-64287-0

ISBN 978-1-349-13825-8 (eBook)

DOI 10.1007/978-1-349-13825-8

A catalogue record for this book is available

from the British Library.

$\begin{array}{llllllllll}10 & 9 & 8 & 7 & 6 & 5 & 4 & 3 & 2 & 1\end{array}$

$\begin{array}{llllllllll}05 & 04 & 03 & 02 & 01 & 00 & 99 & 98 & 97 & 96\end{array}$

Editing and origination by Aardvark Editorial, Suffolk 


\section{Contents}

Foreword by Emmy van Deurzen-Smith vii

Preface $\quad \mathrm{x}$

Acknowledgements xii

List of Abbreviations xiii

Introduction 1

1 Here come the carers 9

2 Counselling plc? 18

3 Who shall be our counsellor? 49

4 'Client-centered' approaches 65

5 Cognitive-behaviourist approaches 92

6 Psychodynamic approaches 109

7 Transpersonal approaches 135

8 Conclusion 155

$\begin{array}{ll}\text { Summary questions } & 178\end{array}$

$\begin{array}{ll}\text { Suggested reading } & 182\end{array}$

$\begin{array}{ll}\text { Index } & 189\end{array}$ 


\section{Foreword}

What does it say about a society when one of its main growth industries is that of counselling and psychotherapy? What does it say about a culture when people need to turn to experts in order to learn how to manage their day-to-day lives and their ordinary human relationships? Alienation, loneliness and meaninglessness are rife at the turn of this millennium. Theories and methods to alleviate these scourges of human well-being and mental health are equally plentiful; critical analyses of their pros and cons are much more scarce.

This is not surprising. The care professionals are too busy perfecting and packaging their products, and their clients are too preoccupied consuming them, to wonder about the justification of all this effort. The emphasis is on income rather than on outcome, on survivial rather than on rationale. There is enough stress simply trying to deal with the human distress around us. There seems little time or energy left to oversee the situation and take stock of it. Few people have the capacity or the inclination to take the overall, birds-eye view. It is not easy to oversee a situation in which one is deeply involved oneself. It is even harder to articulate it, especially when this requires one to warn others of the pitfalls and the dangers that we are collectively running into.

It is said that desperate times require desperate measures. It is probably true to say that people are fairly desperate before they consult a counsellor or a therapist. They are desperate to find solutions to the personal problems they feel surrounded, invaded and overwhelmed by. They are urgently looking for a way out of the humdrum and unsatisfactory lives that wear them out. They are yearning to find some sense of comfort and meaning in a world that seems increasingly set against 
them. Living is not easy at the best of times. For many people in our day and age, living has simply become impossible. Their need is a desperate one.

Counselling and therapy are often the last resort for those who experience such agony and anguish, and there are increasing numbers of people who cannot find help in any other way. Psychotherapy and counselling are no longer merely marginal: they have become a cultural phenomenon. Because of this, these professions have been catapulted into prominence in a few decades, and they have not had the time, attention or research lavished on them to develop solid professional frameworks capable of underpinning the escalating demands made on them. The theory and practice of these professions is still full of holes and is likely to remain so for the foreseeable future.

The question is whether counselling and therapy provide at least adequate remedies, whether they are resources worth employing for the benefit of humankind. It is also relevant to ask whether we can afford not to employ them and whether there are any suitable alternatives.

Faced with the proliferation of counselling and therapeutic methods, I have myself taken the view that the priority was to begin by setting higher standards of training and practice and regulate against abuse. You have to define and develop a field and agree the basic rules of the game before you can begin to play it and learn about its possibilities and limitations.

Robust questioning is the hallmark of a profession that is well enough established to be flexible and capable of thriving on critique. I would like to think that counsellors and therapists can now be confident enough to withstand a radical rethinking of their professional objectives and practice. It may be too much to expect the old guard to show such agility. It may also be unrealistic to expect those preoccupied with securing their professional identity to resonate with the challenging tone of this book. Those who are absorbed in the power-broking that Alex Howard poignantly refers to as operating unknowingly, automatically and without conspiracy, will find it hard to stomach this forceful blow to their self-esteem.

Those who are less enthralled by their profession and more willing to question and be questioned will find this book articulate and incisive. It will give them much to chew over and digest for themselves. Those who are responsible for the training of a new generation of professionals will be aware of the need to bring these questions to the 
attention of their trainees and students, helping them to shake the superficial certainties behind which it is so tempting to hide.

As Alex Howard suggests, the questions raised in this book will make life more difficult for counsellors and their clients. I would add that, equally, when these questions are not being asked or tackled, they make our lives difficult. As long as we avoid these fundamental and philosophical issues, they continue to persecute us and spoil our practice, giving us bad consciences into the bargain. When we begin to ask these questions openly, undeterred by having to admit our human fallibility as experts on human issues, we come a lot closer to a budding understanding of life.

The debate that this book will generate deserves to be a public one, rather than one contained in the pages of the professional literature. The question of whether it is feasible professionally to care for others and whether and how it is possible to increase emotional, personal and relational well-being does not just concern counsellors and psychotherapists: it is relevant to any of us who struggle to make the most of our individual lives under increasingly stressful conditions. 


\section{Preface}

In the following pages, some tough questions are posed about the explosive growth of counselling and psychotherapy. Some in the therapy industry will, I hope and presume, stand up for themselves and provide answers. They will show that they mean business, know their profession and deserve to remain employed. Others will prove to be unequal to the challenges put forward in this book. They will feel undermined. They will deserve to be undermined.

I do not have answers to many of the questions I raise. I do not know which versions of therapy will grow, survive or decline in the critical debate about the nature and future of counselling. I do, however, feel confident that the questions raised are important, and that there is a rather urgent need for some answers.

Who can we turn to when we need support from another human being? It's a vast question. A third party might sometimes be needed, to whom we can talk in confidence. Our ancestors must have known that. What is really new about counselling is the word, rather than the activity. It is also well known that whenever we confide in anyone, there are inevitable risks as well as opportunities. Are the dangers less, and the benefits greater, if we take our problems to a counsellor rather than a lay person or another professional?

If and when counsellors can confidently answer yes to this key question their future will be assured, but how big is the 'If'? Will every style of counselling receive such a positive clearance? I very much doubt it. The following pages will, I hope, help readers to clarify their own views. I wish to contribute some of the questions. Answers may take more time. The court of public opinion is still sitting as regards an overall assessment of counselling. 


\section{For the general reader, and possible users of counselling...}

By the time you have finished this book, you are going to see why it is even harder to find a reliable counsellor than a reliable plumber; at least we know what successful plumbers are supposed to be doing. Hopefully, this will make you cautious. It does not mean you have to despair. Counsellors and therapists are human beings just like any one else, and it is not at all certain that they can fix psychological leaks and blockages in their own lives, or in yours, any better than you can. Are they, however, a useful third party to turn to? They can be. They are most beneficial when you know you must relate to a fallible human being who cannot offer any kind of miracle cure, and when they see themselves with humility and humour. Decide for yourself. Hopefully, this book will help you be aware of, and beware, the dangers and pitfalls.

\section{For counsellors, therapists and other care professionals...}

The questions raised in this book are likely to put care professionals under considerable pressure; from clients, trainers, colleagues and their own consciences. I am raising fundamental concerns about the very foundations of counselling theory and practice, and this may threaten some people's self-esteem and material livelihood. Is this constructive and necessary? I think it is. Stronger roots and better boundaries are needed if the whole enterprise is to avoid a major capsize.

It is pretty well impossible to be impartial about a profession within which our status and material security is invested. However, it is cynical to go on promoting counselling without strengthening its flimsy base, and this is not in the best long-term interests of counsellors or their clients. 


\section{Acknowledgements}

Thanks to all who read and commented. In particular, to Colin Feltham for early encouragement; to Windy Dryden; to Emmy van Deurzen-Smith for her much prized efforts to show me the need for a calmer, more disciplined tone. To my wife, Jane Wheelock, for toleration, love, and a visceral ability to coax me towards seeing that major revisions were needed. To my editors at Aardvark Editorial, for cleaning up the text, and to Frances Arnold, publisher at Macmillan, for her own, most helpful, challenges. To these people, I hope I have listened effectively. If I have not, the fault and the responsibility are my own.

The author and publishers wish to thank Personnel Psychology for permission to reproduce the table on page 173 by Ross Stagner.

Every effort has been made to trace the copyright holders but if any have been inadvertently overlooked, the publishers shall be glad to make the necessary arrangement at the first opportunity. 


\section{List of Abbreviations}

BAC British Association for Counselling

BPS British Psychological Society

EAP European Association for Psychotherapy

EAC European Association for Counselling

HMI Her Majesty's Inspectorate (of Education)

NVQ National Vocational Qualification

UKCP United Kingdom Council for Psychotherapy 